\title{
FEASIBILITY ANALYSIS OF GYROPLANE DEVELOPMENT IN INDONESIA
}

\author{
Dominggo Bayu Baskara', Christiono Utomo \\ ${ }^{I}$ Department of Technology Management, Institut Teknologi Sepuluh Nopember, Surabaya, Indonesia \\ ${ }^{2}$ Department of Civil Engineering, Institut Teknologi Sepuluh Nopember, Surabaya, Indonesia
}

\begin{abstract}
Gyroplane is a personal aircraft technology that use autorotation mechanism to achieve lift. Because its main rotor always in autorotation state, gyroplane can glide easily from any height even with the engine being off. This make gyroplane offers inherent safety, simplicity of operation, and outstanding short field point-to-point capability. Because of this technology has been developed in many European country, and Indonesia archipelago landscape makes many area suffer lack of support in road infrastructure, this situation creates potential market for gyroplane technology adoption in Indonesia.PT Bayu Aircraft Indonesia is a start-up company that currently working in gyroplane technology development project. Ensuring the success from this project, it is essential to asses project feasibility to see whether or not this technology development project may bring benefit financially for the company and its stakeholder. From technical perspective, the initial cost necessary to run the project is IDR 2,188,270,000. In which this amount of money will be used to provide production facility, research cost, legal cost, pre-operation, etc. From economic perspective using capital budgeting it is estimated that the competitive selling price is IDR 549,752,788 with margin rate $35,45 \%$. Using cashflow analysis, the project is feasible with IRR $81.93 \%$ which is more than MARR at $12 \%$. NPV from this project is IDR 7,161,680,064 and Paypack Period in the second year. The feasibility boundary of this project are: Engine cost maximum rising at $+28.44 \%$, USD to IDR exchange rate maximum rising at $+25.72 \%$, sales maximum declining at $60.97 \%$, and profit margin maximum declining at $-21.62 \%$.
\end{abstract}

Keywords: Gyroplane, Technology Adoption, Feasibility Study, Capital Budgeting

\section{INTRODUCTION}

Gyroplane is a personal aircraft technology that use autorotation mechanism to achieve lift. Because its main rotor always in autorotation state, gyroplane can glide easily from any height even with the engine being off. This make gyroplane offers inherent safety, simplicity of operation, and outstanding short field point-to-point capability. Because of this technology has been developed in many European country, and Indonesia archipelago landscape makes many area suffer lack of support in road infrastructure, this situation creates potential market for gyroplane technology adoption in Indonesia.

The Republic of Indonesia has the largest archipelago in the world. With the geographical condition, however, there are still several areas that are isolated and difficult to reach, even not accessible by road. These conditions will make it difficult for the Government in an effort to build connectivity between areas in an attempt to equitable development. The air transportation is one of the pioneering efforts to open these isolated areas.

The need for the addition of air transport pioneer in Indonesia is very high, but the number of manufacturer does not seem to add up. Therefore, this study was made with the purpose of finding out whether the development of the new aircraft type called gyroplane in Indonesia will be feasible or not from the financial point of view. Since gyroplane numbers has gone up in europe recently[1].
PT. Bayu Aircraft Indonesia is a start-up company that currently working in gyroplane technology development project. Ensuring the success from this project, it is essential to asses project feasibility to see whether or not this technology development project may bring benefit financially for the company and its stakeholder.

\section{LITERATURE REVIEW}

\section{Feasibility Study}

Feasibility study is a research method of a project designed to uncover the strengths and weaknesses of the project and determine whether the project is feasible or not. (Jakfar and Kasmir, 2010)[2]. The result of the feasibility study will show whether the project or business can make a profit or not, so that the project manager or owner can make a further long-term decisions about the project itself.

\section{Present Value}

Present Value (PV) is the current dollar value of a future amount-the amount of money that would have to be invested today at a given interest rate over a specified period to equal the future amount(Gitman, 2012)[3]. In this study, the Present Value will be used to calculate the project's revenue for a specified time. The revenue for the specified time will be calculated so the present value can be determined, then it will results the Net Present Value.

$$
P V=\frac{F V}{(1+i)^{2}}
$$




\section{Net Present Value (NPV)}

Net Present Value (NPV) is a sophisticated capital budgeting technique; found by subtracting a project's initial investment from the present value of its cash inflows discounted at a rate equal to the firm's cost of capital (Gitman, 2012). Net Present Value is the difference between an investment's market value and its cost.

$N P V=\sum$ Present Value of After Tax Cash Flow -Investment + Residual Value

\section{Internal Rate of Return (IRR)}

Internal rate of return (IRR) is one of the most widely used capital budgeting techniques. It means that the discount rate that equates the NPV of an investment opportunity with $\$ 0$ (because the present value of cash it inflows equals the initial investment). It is the rate of return that the firm will earn if it invests in the project and receives the given cash inflows.

In this study, the calculation of IRR will be done by using Microsoft Excel 2007's formula, which is "=IRR(values, [guess])", where the "values" itself will be taken from the series of after tax cash flow from year 2016 until year 2021, and "guess" value will be drawn from a random guess

\section{Payback Period (PBP)}

Payback period is also known as Break Even Period. The result of the payback period can determine two conditions. The first one is if the payback period is less than the maximum acceptable payback period, then the project can be accepted. But if the payback period is greater than the maximum acceptable payback period, then the project must be rejected. Payback period also can make a huge impact to the management, which will lead to value-creating investment decisions. Below is the formula that can be used for calculating the payback period.

$$
\text { Payback Period }=Y+\frac{A}{B}
$$

Whereby:

- $\mathrm{Y}=$ the number of years before final payback years

- $\mathrm{A}=$ total remaining to be paid back at the start of the payback year, to bring cumulative cash flow to $\$ 0$

- $\mathrm{B}=$ total (net) paid back in the entire payback year

\section{Depreciation}

Depreciation is a portion of the costs of fixed assets charged against annual revenues over time(Gitman, 2012). There are four common methods to determine depreciation; which are, Straight line method, Sum-of-the-year digits, Declining Balance, Sinking Fund, Modified Accelerated Cost Recovery System (MACRS). This study will be using the straight line method which is the simplest method calculated by taking the purchase value of an asset and subtracting it by salvage value of the asset. The result will be used as the depreciation for each of the productive years. The formula is as follows.

$$
\text { Depreciation }=\frac{\text { Cost of the Asset }- \text { Residual Value }}{\text { Useful Life of the Asset }}
$$

\section{Minimum Acceptable Rate of Return (MARR)}

Minimum Acceptable Rate of Return (MARR) is a minimum returns a company will accept on the money it invests. MARR can be calculated from evaluating MARR scenarios including Indonesia Government Bond Rate as risk free rate reference, Bank Mandiri loan rate, and similar project MARR in Indonesia. In this study, the MARR that will be used is $12 \%$ that comes from similar aircraft project in Indonesia[4] which develop N219 Aircraft by PT Dirgantara Indonesia. This MARR is highest among Indonesia Government Bond Rate and Bank Mandiri loan rate which rates $6.75 \%$ and $10.25 \%$ respectively. The project will be considered as feasible if the IRR of the project is greater than the MARR (IRR $>$ MARR).

\section{Sensitivity Analysis}

Sensitivity analysis can be used to help prevent rash predictions about the outcome of plans by ensuring that the assumptions on which the plans are based were examined and the effect of changes in these assumptions is gauged (Armstrong, 2006)[5]. The result of the sensitivity analysis is to determine the sensitivity level of the gyroplane development project. In this study, the factors that will be used on this sensitivity calculation are Engine cost, USD to IDR exchange rate, sales projection, and profit margin.

\section{METHODOLOGY}

There will be 5 steps on doing this feasibility study; which are Problem Identification, Literature Study, Data Collection, Data Processing and Analyzing, and Conclusion and Recommendation. These steps need to be done in order to complete the project.

\section{DATA COLLECTION}

The main components of the cost are the investment cost, the fixed cost and the variable operating cost. The sources of the data are coming from PT Bayu Aircraft Indonesia, government regulation, and several assumptions. The cost and revenue calculation is done per product that are produced during 5 years of project lifetime

\section{DATA ANALYSIS}

\subsection{Initial Cost}

\section{Investment Cost}

According to the source in PT. Bayu Aircraft Indonesia, the investment cost needed to develop gyroplane is IDR2,188,270,000 including research and development cost, licensing cost, were house lease, office equipment, production facility, and pre-operational cost. The number of aircraft produce in this study are 120 unit during 5 years of project lifetime. For the simplicity of the study, it is assumed that it will be a onetime payment for the investment. The yearly depreciation that will be used to calculate is coming from production facility which cost $348,270,000$ consist of machinery unit, pickup car, welding unit, etc.. Applying the depreciation period of 5 years and zero residual value of production facility, the yearly depreciation become: IDR 394,896,000. 


\section{Overhead Cost}

According to the source in PT. Bayu Aircraft Indonesia, the overhead cost during project lifetime is IDR 200,000,000 per year including power, fuel, and marketing cost. Also there will be 10 people operate the production facility and minimum wage in the project area is IDR 3,290,800 per month for each operator. In conclusion salary cost is IDR 394,896,000 Annualy

\subsection{Selling Price}

\section{Fixed Cost}

The fixed cost from this research shown by table 1 can be concluded from summary of investment cost and overhead cost during project lifetime

Table -1: Fixed Cost Table

\begin{tabular}{|l|l|}
\hline Investment Cost & IDR $1,840,000,000$ \\
\hline Production facility cost & IDR $348,270,000$ \\
\hline Overhead Cost & IDR $1,000,000,000$ \\
\hline Depreciation Cost(5 yr) & IDR 348,270,000 \\
\hline Salary Cost (5 yr) & IDR $1,974,480,000$ \\
\hline Total Fixed Cost & IDR 5,511,020,000 \\
\hline
\end{tabular}

The summary total fixed cost IDR 5,511,020,000 then divided by 120 unit product that planned to produce. In coclusion average fixed cost per product is IDR 45,925,167.

\section{Variable Cost}

The variable cost from this research concluded from the cost of assembly per product. According to the source in PT.
Bayu Aircraft Indonesia it needs IDR 359,957,106 to produce each products consist of each component price. The gyroplane will be made to order, so there is no logistic cost. Since the product only be made when there is an order from customer. The engine block is the most expensive component, that $95 \%$ of the variable cost comes from it. Therefore the sensitivity of engine cost needs to be analyzed

\section{Margin}

By adding fixed and variable cost, the total cost for each product is IDR $405,882,27$. Then from total cost, minimums selling price than can be known from data processing using cash flow analysis method. Therefore the margin number added to total cost that makes $\mathrm{NPV}=0$ is the minimum margin to achieve MARR $12 \%$.

\section{Cashflow Analysis}

Table 3 below presents the yearly operation costs for each route. During 5 years project lifetime and 120 unit produce. But before the cash flow analysis, table 2 show financial assumption used in this research.

Table -2: Financial Assumption

\begin{tabular}{|l|l|}
\hline Investment cost & IDR $1,840,000,000$ \\
\hline Production Facility cost & IDR $348,270,000$ \\
\hline Depreciation cost & IDR $69,654,000 /$ year \\
\hline Overhead cost & IDR $200,000,000 /$ year \\
\hline Salary cost & IDR $394,896,000 /$ year \\
\hline Harga Pokok Produksi & IDR 405,882,273/unit \\
\hline USD to IDR exchange rate & IDR $13,422 /$ USD \\
\hline
\end{tabular}

Table -3: Projected Cashflow

TABEL ALRAN DANA PROYEK PENG EMBANGAN GYROPLANE

\begin{tabular}{|c|c|c|c|c|c|c|c|c|c|c|}
\hline Keterangan & Volume & Satua & Harga Satuan & Total & Tahun 0 & Tahun 1 & Tahun 2 & Tahun 3 & Tahun 4 & Tahun 5 \\
\hline 1 & 2 & 3 & 4 & 5 & 6 & 7 & 8 & 9 & 10 & 11 \\
\hline \multicolumn{11}{|l|}{ INITIAL CASH FLOW } \\
\hline \multicolumn{11}{|l|}{ Initial Cost } \\
\hline Biaya Investasi & & & & $1,840,000,000$ & & & & & & \\
\hline Biaya Fasilitas Produksi & & & & $348,270,000$ & & & & & & \\
\hline Total Initial Cost & & & & $2,188,270,000$ & $(2,188,270,000)$ & & & & & \\
\hline \multicolumn{11}{|l|}{ OPERATIONAL CASH FLOW } \\
\hline \multicolumn{11}{|l|}{ Operational Cash Out } \\
\hline Cicilan hutang (A/P, $12 \%, 5 y r)$ & & & 0.277410 & - & & - & - & - & - & - \\
\hline Biaya Overhead & & & $200,000,000$ & & & $(200,000,000)$ & $(200,000,000)$ & $(200,000,000)$ & $(200,000,000)$ & $(200,000,000)$ \\
\hline Depresiasi Alat & & & $69,654,000$ & & & $(69,654,000)$ & $(69,654,000)$ & $(69,654,000)$ & $(69,654,000)$ & $(69,654,000)$ \\
\hline Beban Gaji & 10 & org & $3,290,800$ & $394,896,000$ & & $(394,896,000)$ & $(394,896,000)$ & $(394,896,000)$ & $(394,896,000)$ & $(394,896,000)$ \\
\hline Biaya Pokok Produksi & & & $405,882,273$ & & & $(4,870,587,272)$ & $(7,305,880,908)$ & $(9,741,174,544)$ & $(12,176,468,180)$ & $(14,611,761,816)$ \\
\hline Sub Total Cash Out & & & & & & $(5,535,137,272)$ & $(7,970,430,908)$ & $(10,405,724,544)$ & $(12,841,018,180)$ & $(15,276,311,816)$ \\
\hline Operational Cash In & & & & & & & $150 \%$ & $200 \%$ & $250 \%$ & $300 \%$ \\
\hline Proyeksi Penjualan & & & & & & 12 & 18 & 24 & 30 & 36 \\
\hline Harga Jual/HPP & $12.68 \%$ & & 0.1268 & $457,338,086$ & & $5,488,057,032$ & $8,232,085,548$ & $10,976,114,065$ & $13,720,142,581$ & $16,464,171,097$ \\
\hline Sub Total Cash in & & & & & & $5,488,057,032$ & $8,232,085,548$ & $10,976,114,065$ & $13,720,142,581$ & $16,464,171,097$ \\
\hline Net Operating Income & & & & & & $(47,080,240)$ & $261,654,641$ & $570,389,521$ & $879,124,401$ & $1,187,859,281$ \\
\hline NET CASHFLOW & & & & & $(2,188,270,000)$ & $(47,080,240)$ & $261,654,641$ & $570,389,521$ & $879,124,401$ & $1,187,859,281$ \\
\hline DISC. FACTOR & $6.75 \%$ & & 0.0675 & & 1.0000 & 1.0675 & 1.1396 & 1.2165 & 1.2986 & 1.3862 \\
\hline DISCOUNTED CASHFLOW & & & & & $(2,188,270,000)$ & $(44,103,269)$ & $229,610,992$ & $468,886,671$ & $676,984,616$ & $856,890,991$ \\
\hline CUMMULATIVE CASHFLOW & & & & & $(2,188,270,000)$ & $(2,232,373,269)$ & $(2,002,762,277)$ & $(1,533,875,607)$ & $(856,890,991)$ & $\underline{0}$ \\
\hline NPV & & & & 0 & & & & & & \\
\hline$\underline{I R R}$ & & & & $6.75 \%$ & & & & & & \\
\hline PAYBACK PERIOD & & & & 5TAHUN & & & & & & \\
\hline
\end{tabular}


The minimum margin to achieve MARR $12 \%$ is $12,68 \%$ from total cost. Therefore the minimum selling price is IDR $457,338,086$. Then the competitive price of the gyroplane needs to be known as maximum price reference. In order to get the competitive price than similar product that has similar specification than picked as benchmark. It is known that ELA 07S gyroplane manufactured by ELA Aviaccion in Spain has similar specification. And its selling price according to World Directory of Light Aviation 2015[7] is IDR 549,752,788.15. This competitive price than analyzed using the same cashflow analysis method in table 3 . And the result as follows:

- $\quad$ NPV: IDR 7,161,680,064

- IRR: $81.93 \%$

- PBP: 2 years

- BEP: $30^{\text {th }}$ unit
Because the NPV of the project has positive value. Therefore the project is feasible if the product is sold between is IDR 457,338,086 to IDR 549,752,788.15.The IRR of the project is $81.93 \%$, which is much higher than the set cost of money, which is set to be equal of the assumed interest rate $12 \%$. The project is then rated to be feasible. In the common practice of airline operation, similar to other transportation business, the average payback period is about 5 years. This project PBP is 2 years, which mean the project is interesting to the investor.

\section{Sensitivity Analysis}

In this study, there are some variable that possible to make the project to be not feasible during actual project implementation because there might be deviate from planning. which is: Engine cost, USD to IDR exchange rate, sales projection, and profit margin.

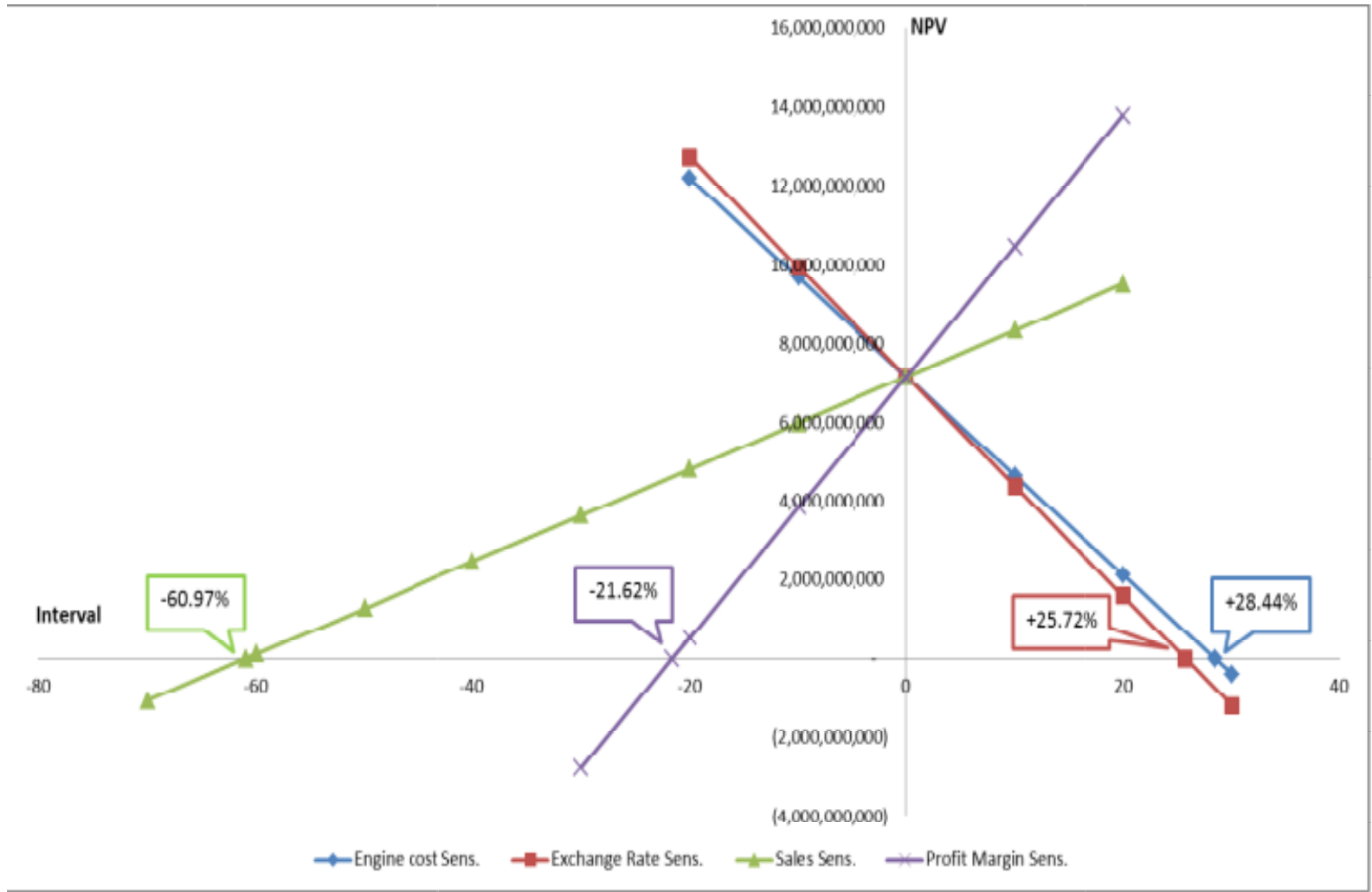

Chart -1: Sensitivity Chart

According to chart 1 the sensitivity analysis results as follows: Engine cost maximum rising at $+28.44 \%$, USD to IDR exchange rate maximum rising at $+25.72 \%$, sales maximum declining at $-60.97 \%$, and profit margin maximum declining at $-21.62 \%$. This number become boundary of project feasibility that may risk the success of the project. The project manager should be aware when the actual project reach this certain number.

\section{CONCLUSION}

From the results of data analysis, the conclusion fro this research is as follows:
1. Using capital budgeting the project is feasible if the product is sold between is IDR 457,338,086 to IDR $549,752,788.15$.

2. Using cashflow analysis, the project is feasible with IRR $81.93 \%$ which is more than MARR at $12 \%$. NPV from this project is IDR 7,161,680,064 and Paypack Period in the second year.

3. The feasibility boundary of this project are: Engine cost maximum rising at $+28.44 \%$, USD to IDR exchange rate maximum rising at $+25.72 \%$, sales maximum declining at $-60.97 \%$, and profit margin maximum declining at $-21.62 \%$. 


\section{ACKNOWLEDGEMENT}

The authors can acknowledge any person/authorities in this section. This is not mandatory.

\section{REFERENCES}

[1]. Aerokurier Magazin, (2016), Gyro Statistisch, MotorPresse Stuttgart, Germany

[2]. Jakfar and Kasmir., (2010), "Studi Kelayakan Bisnis", Prenada Media, Jakarta.

[3]. Giatman, M. (2006), "Ekonomi Teknik”, Raja Grafindo Persada, Jakarta

[4]. Lubis, A., dan Surya, B.A., (2014), "Feasibility Analysis Of N219 Aircraft Routing In Timika", Journal of Business and Management, Vol. 3, No. 2, pg. 255-266.

[5]. Armstrong, B. 2006. "Models for the relationship between ambient temperature and dailymortality." Epidemiology 17:624-631.

\section{BIOGRAPHIES}

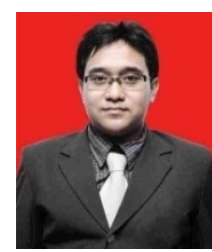

Student of Magister program in Project management, Institut Teknologi Sepuluh Nopember, Surabaya, Indonesia. Innovation enthusiast with passion to learn new technology. Dreaming to become professional in reverse engineering.

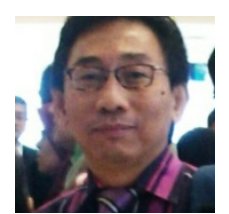

Lecturer of Magister program in Department of Civil Engineering, Institut Teknologi Sepuluh Nopember, Surabaya, Indonesia. Have proficiency in both ptoject financial analysis and construction management. Holds doctoral degree in both economic studies and civil engineering. 